\title{
KLASIFIKASI OBAT GAWAT DARURAT MENGGUNAKAN ANALISIS ABC- VED DI INSTALASI FARMASI RSUD Dr MOEWARDI SURAKARTA
}

\author{
Oleh : Miftakhul 'Arfah Hadiani
}

\begin{abstract}
Abstrak
RSUD Dr Moewardi adalah rumah sakit pemerintah daerah Tingkat I propinsi Jawa Tengah di Surakarta yang menjadi tempat pelayanan kesehatan. Salah satu sumber daya rumah sakit yang penting adalah perbekalan farmasi yaitu obat yang merupakan sarana penting dalam proses penyembuhan pasien. Obat yang harus disediakan sekitar 1200 jenis terbagi dalam obat gawat darurat dan obat bukan gawat darurat. Obat gawat darurat bersifat Life Saving yang diperlukan pada keadaan gawat darurat untuk menyelamatkan jiwa atau mencegah terjadinya kematian dan kecacatan seumur hidup. Dalam melakukan pengendalian persediaan obat, rumah sakit belum mengklasifikasikan nilai pemakaian obat dan tingkat kekritisannya melalui suatu metode pengklasifikasian tertentu. Dalam penelitian ini dilakukan pengendalian persediaan obat dengan menentukan pembagian obat gawat darurat menggunakan analisis $A B C$ berdasarkan nilai pemakaian obat, dan analisis Vital/Essential/Desirable (VED) berdasarkan tingkat kekritisan pemakaian obat. Dari penelitian pengendalian persediaan obat gawat darurat di Sub Gudang obat Instalasi Farmasi RSUD Dr Moewardi dapat disimpulkan bahwa pada klasifikasi ABC dan VED terdapat 49 jenis obat gawat darurat prioritas I dan 95 jenis obat gawat darurat prioritas II.
\end{abstract}

Kata Kunci : Persediaan, Analisis $A B C$, Analisis VED, Matrik $A B C$-VED

\section{PENDAHULUAN}

Persediaan adalah suatu elemen yang penting dalam operasional badan usaha. Tanpa adanya persediaan badan usaha akan dihadapkan pada risiko tidak dapat memenuhi kebutuhan para langganan sehingga mengakibatkan target pelayanan terhadap pelanggan tidak terpenuhi.

Pengendalian persediaan obat memiliki arti yang sangat penting karena merupakan salah satu faktor yang mempengaruhi pelayanan rumah sakit. Pengendalian persediaan obat di RSUD DR Moewardi dipusatkan di bagian Instalasi Farmasi khususnya bagian Sub Gudang Obat. Sub Gudang obat memenuhi permintaan obat dari Apotek Gawat Darurat, Apotek rawat Jalan $(1,2,3)$, Apotek Rawat Intensif, Apotek Mawar $(1,2,3)$, Apotek Melati $(1,2,3)$, Apotek Anggrek (1,2,3), Apotek Cendana (1,2,3), Apotek Instalasi Bedah Sentral. Obat yang harus disediakan oleh Instalasi farmasi tertuang dalam Formularium Rumah Sakit yaitu sekitar 1200 jenis terdiri dari obat bukan generik berlogo dan generik berlogo serta dipesan dari 19 supplier.

Selama ini rumah sakit mempunyai kebijakan mengenai biaya yang harus dikeluarkan untuk pengadaan obat. Anggaran pengadaan obat ditetapkan untuk satu tahun kemudian dibagi untuk tiap bulannya. Ada dua kebijakan pengadaan obat yaitu sistem beli (non konsinyasi) dan sistem kontrak (konsinyasi). Dalam sistem beli, obat dipesan dan langsung dibayar setelah obat datang, sedangkan dalam sistem kontrak (konsinyasi) pihak rumah sakit melakukan kontrak dengan supplier kemudian obat dipesan dan pembayaran dilakukan setelah obat laku, apabila tidak laku obat boleh dikembalikan sesuai dengan persetujuan dalam kontrak. Kebijakan sistem kontrak (konsinyasi) ini untuk menghindari kekurangan dana.

Pengendalian persediaan obat di Sub Gudang Obat Instalasi Farmasi membutuhkan kontrol yang lebih karena melibatkan ribuan obat dan puluhan supplier. Rumah sakit saat ini belum memisahkan kontrol terhadap jenis-jenis obat yang dipesan.

Berdasarkan sifat pemakaiannya obat-obat yang tertuang dalam Formularium Rumah Sakit dibedakan dalam dua jenis yaitu obat gawat darurat dan obat bukan gawat darurat. Obat gawat darurat merupakan sebagian dari obat-obatan yang harus ada dalam persediaan ruangan, obat ini mutlak harus selalu tersedia di setiap ruangan karena pengaruhnya yang begitu besar terhadap pelayanan yang terkait.

\footnotetext{
*) Dosen Teknik Industri

Universitas PGRI Adi Buana Surabaya
} 
Obat ini bersifat life saving yang diperlukan pada keadaan gawat darurat untuk menyelamatkan jiwa atau mencegah terjadinya kematian dan kecacatan seumur hidup. Berdasarkan kekritisan waktu pemberian obat kepada pasien obat gawat darurat dibedakan menjadi 3 kategori yaitu Obat kategori Vital, Essential dan Desirable (VED). Obat kategori Vital adalah obat yang sangat dibutuhkan pasien dengan segera untuk menyelamatkan hidup, obat kategori ini mutlak tersedia sepanjang waktu dalam persediaan ruangan. Kekosongan obat jenis ini akan berakibat fatal dan tidak dapat ditoleransi. Obat kategori Essential adalah obat yang dibutuhkan oleh pasien, kekritisan waktu pemberian obat lebih rendah dibandingkan kategori vital, masih ada toleransi kekosongan selama tidak lebih dari 24 jam. Obat kategori Desirable adalah obat yang dibutuhkan oleh pasien, kekritisan waktu pemberian obat paling rendah dibandingkan Vital dan Essential, masih ada toleransi kekosongan selama tidak lebih dari 48 jam . Obat bukan gawat darurat merupakan obat-obat selain obat gawat darurat yang dibutuhkan oleh pasien rawat inap, rawat jalan maupun pasien umum. Dalam satu tahun, nilai pemakaian 144 jenis obat mencapai Rp.4,7 M atau 39,18\% dari total nilai pemakaian obat di RSUD $\mathrm{Dr}$ Moewardi.

Mengingat banyaknya jenis obat gawat darurat yang harus tersedia, maka pada penelitian ini dilakukan pengelompokan melalui analisis $A B C$ dan VED terhadap obat jenis tersebut. Klasifikasi obat gawat darurat dengan menggunakan analisis $\mathrm{ABC}$ dan analisis VED menurut V.R. Thawani et al (2004) yaitu dari analisis ABC dan VED diperoleh matrik, berdasarkan matrik tersebut obat dibedakan dalam 2 prioritas. Prioritas I merupakan obat yang membutuhkan prioritas manajemen yang lebih besar dalam pengendaliannya yaitu kelompok AV, AE, AD, BV, dan BE. Prioritas II merupakan obat yang membutuhkan prioritas manajemen yang lebih rendah dalam pengendaliannya yaitu kelompok BD, CV, CE, dan CD (abjad pertama menyatakan analisis $A B C$ dan abjad kedua menyatakan analisis VED). Matrik analisis $A B C$ dan analisis VED terlihat dalam Tabel 1.
Tabel 1. Tabel Matrik Analisis ABC dan Analisis VED

\begin{tabular}{cccc}
\hline Kategori Obat & A & B & C \\
\hline V & AV & BV & CV \\
E & AE & BE & CE \\
D & AD & BD & CD
\end{tabular}

Keterangan : Cetak Tebal $=$ Prioritas I, Normal $=$ Prioritas II

Sumber : V.R. Thawani et al (2004)

\section{Perumusan Masalah}

Berdasarkan latar belakang masalah, dapat dirumuskan permasalahan yaitu bagaimana mengklasifikasikan obat gawat darurat dengan menggunakan analisis ABC dan analisis VED untuk mempermudah pengendalian obat gawat darurat.

\section{Tujuan Penelitian}

Tujuan dari kegiatan penelitian ini adalah mengklasifikasikan obat gawat darurat dengan menggunakan analisis $A B C$ dan analisis VED untuk mempermudah pengendalian obat gawat darurat.

\section{Manfaat Penelitian}

Manfaat yang ingin diperoleh dengan adanya penelitian ini adalah memberikan masukan kepada rumah sakit dalam merencanakan kebutuhan obat melalui klasifikasi obat gawat darurat.

\section{Batasan Masalah}

Agar sasaran dalam studi lapangan ini tercapai, maka diperlukan batasanbatasan sebagai berikut :

1. Periode permintaan obat dan pengeluaran obat yang diteliti adalah periode tahunan.

2. Obat yang diteliti adalah obat sistem beli (non konsinyasi).

\section{TINJAUAN PUSTAKA Manajemen Persediaan}

Persediaan adalah bahan atau barang yang disimpan untuk memenuhi tujuan tertentu, misalnya untuk proses produksi atau perakitan, untuk dijual kembali, dan untuk suku cadang bagi mesin. Persediaan dapat berupa bahan mentah, bahan pembantu, barang dalam proses, barang jadi, ataupun suku cadang. Tidak ada perusahaan yang beroperasi tanpa persediaan, meskipun sebenarnya persediaan hanyalah suatu sumber dana yang menganggur, karena sebelum persediaan digunakan berarti dana yang terikat di dalamnya tidak dapat digunakan untuk keperluan yang lain (Herjanto,1999). 
Menurut Herjanto (1999), sistem pengendalian persediaan adalah mekanisme mengenai bagaimana mengelola masukanmasukan yang sehubungan dengan persediaan menjadi output, di mana untuk itu diperlukan umpan balik agar output memenuhi standar tertentu.

\section{Sistem Persediaan ABC}

Menurut Herjanto (1999), metode pengendalian persediaan $A B C$ didasarkan pada hubungan distribusi pendapatan yang dikemukakan oleh Pareto bahwa distribusi sebagian pendapatan $(85 \%)$ terpusat pada sebagian kecil individu (15\%) dari total populasi. Hubungan serupa juga terjadi dalam persediaan. Sebagian kecil item persediaan menyebabkan sebagian besar ongkos persediaan keseluruhan. Pengendalian ketat atas item-item dengan biaya yang tinggi akan membawa kepada pengendalian yang efektif atas seluruh biaya persediaan. Metode pengendalian persediaan untuk menangani hal ini dikenal sebagai metode $A B C$, menurut klasifikasi persediaan. Persediaan yang bernilai tinggi digolongkan ke dalam kelas $A$, persediaan yang bernilai sedang digolongkan ke dalam kelas B, dan persediaan bernilai rendah digolongkan ke dalam kelas C. Terdapat perbedaan kebijaksanaan persediaan untuk ketiga kelas ini. Investasi harus ditekan untuk item persediaan kelas A dan B sehingga kebijaksanaan minimasi ongkos harus dilakukan dengan ketat. Item persediaan kelas $\mathrm{C}$ dapat disediakan agak berlebihan dan dengan pengendalian longgar untuk mengurangi resiko kehabisan persediaan.

Penggunakan analisis $A B C$ menurut Fogarty et al (1991) adalah :

1. Frekuensi penghitungan inventori (cycle counting), dimana material-material Kelas A harus diuji lebih sering dalam hal akurasi catatan inventori dibandingkan material-material kelas $\mathrm{B}$ atau $\mathrm{C}$.

2. Prioritas rekayasa (engineering), di mana material-material kelas $A$ dan $B$ memberikan petunjuk pada bagian rekayasa dalam peningkatan program reduksi biaya ketika mencari materialmaterial tertentu yang perlu difokuskan.

3. Prioritas pembelian (perolehan), dimana aktifitas pembelian seharusnya difokuskan pada bahan-bahan baku bernilai tinggi (high cost) dan penggunaan dalam jumlah tinggi (high usage). Fokus pada material-material kelas A untuk pemasokan (sourcing) dan negoisasi.
4. Keamanan: meskipun nilai biaya per unit merupakan merupakan indikator yang lebih baik dibandingkan nilai penggunaan (usage value), namun analisis $A B C$ boleh digunalan sebagai indikator dari materialmaterial mana (kelas A dan B) yang seharusnya lebih aman disimpan dalam ruangan terkunci untuk mencegah kehilangan, kerusakan atau pencurian.

5. Sistem pengisian kembali (replenishment system), dimana klasifikasi ABC akan membantu mengidentifikasikan metode pengendalian yang digunakan. Akan lebih ekonomis apabila mengendalikan material-material kelas $\mathrm{C}$ dengan simple two-bin system of replenisment (sinonim: bin reserve system or visual review system) dan metode-metode yang lebih canggih untuk material-material kelas $A$ dan B.

6. Keputusan investasi, karena materialmaterial kelas $A$ menggambarkan investasi yang lebih besar dalam inventori, maka perlu lebih berhati-hati dalam membuat keputusan tentang kuantitas pesanan dan stok pengaman terhadap material-material kelas $A$ dibandingkan terhadap materia-material kelas B dan C.

\section{Analisis Vital, Essential, Desirable (VED)}

Menurut Thawani et al (2004), klasifikasi obat menggunakan analisis VED bertujuan untuk mengklasifikasikan obat berdasarkan kekritisan waktu pemberian obat kepada pasien. Kategori obat tersebut adalah :

1. Obat kategori Vital adalah obat yang sangat dibutuhkan pasien dengan segera untuk menyelamatkan hidup, obat kategori mutlak tersedia sepanjang waktu dalam persediaan ruangan.

2. Obat kategori Essential adalah obat yang dibutuhkan oleh pasien, kekritisan waktu pemberian obat lebih rendah daripada kategori vital.

3. Obat kategori Desirable adalah obat yang dibutuhkan oleh pasien, kekritisan waktu pemberian obat paling rendah daripada Vital dan Essential. Obat ini biasanya dalam sedian oral untuk penanganan pasien lebih lanjut.

\section{Persediaan Obat Di rumah sakit}

Menurut Admadi (1995) dalam Yuliastuti (2006), bagian farmasi dari suatu rumah sakit, atau sering dikenal juga dengan sebutan "Apotek", adalah bentuk kegiatan dari sekian banyak bagian kegiatan yang 
umumnya terdapat dalam suatu rumah sakit, yang bertugas/bertindak sebagai penyalur obat-obatan dan barang kesehatan lainnya, bagi pasien atau orang yang membutuhkan. Sehingga keberadaan suatu apotek mempunyai peran yang sangat besar bagi pemulihan kesehatan dan keselamatan jiwa seseorang, serta membantu/mendukung tugas dokter dalam upaya penyembuhan pasien. Dengan perkataan lain, apotek adalah suatu bagian yang tidak dapat diabaikan dalam sistem pelayanan kesehatan. Oleh karena itu, suatu apotek harus selalu mempunyai persediaan yang cukup akan perbekalan farmasi termasuk obat-obatan, sehingga dapat segera memenuhi permintaan. Kekurangan atau tidak tersedianya suatu obat yang diperlukan oleh seorang pasien dapat berakibat fatal bagi jiwa pasien tersebut. Di lain pihak persediaan perbekalan farmasi, khususnya yang berupa obat-obatan mempunyai kadaluarsa tertentu, sehingga penyimpanan obat-obatan juga harus memperhatikan masa kadaluarsanya. Selain itu, pada umumnya harga obat cukup mahal, sehingga penyimpanan obat-obatan yang terlalu banyak juga berarti investasi yang tidak sedikit. Jika pemakaian obat-obatan tersebut agak lambat atau bahkan frekuensinya kecil, berarti terjadi stagnasi modal.

Yusmainita (2005) dalam Suciati dan Adisasmito (2006) menyebutkan bahwa pelayanan farmasi merupakan pelayanan penunjang dan sekaligus merupakan revenue center utama. Hal tersebut mengingat bahwa lebih dari $90 \%$ pelayanan kesehatan di rumah sakit menggunakan perbekalan farmasi (obat-obatan, bahan kimia, bahan radiologi, bahan alat kesehatan habis, alat kedokteran, dan gas medik), dan $50 \%$ dari seluruh pemasukan RS berasal dari pengelolaan perbekalan farmasi. Untuk itu, jika masalah perbekalan farmasi tidak dikelola secara cermat dan penuh tanggung jawab maka dapat diprediksi bahwa pendapatan RS akan mengalami penurunan.
Dengan meningkatnya pengetahuan dan ekonomi masyarakat menyebabkan makin meningkat pula kebutuhan masyarakat terhadap pelayanan kefarmasian. Aspek terpenting dari pelayanan farmasi adalah mengoptimalkan penggunaan obat, ini harus termasuk perencanaan untuk menjamin ketersediaan, keamanan dan keefektifan penggunaan obat. Mengingat besarnya kontribusi instalasi farmasi dalam kelancaran pelayanan dan juga merupakan instalasi yang memberikan sumber pemasukan terbesar di RS, maka perbekalan barang farmasi memerlukan suatu pengelolaan secara cermat dan penuh tanggung jawab (Suciati dan Adisasmito, 2006).

Penggunaan Klasifikasi $A B C$ secara efektif dapat membantu rumah sakit dalam membuat perencanaan obat dengan mempertimbangkan aspek pemakaian dan nilai investasi. Klasifikasi ini akan sangat diperlukan untuk variasi obat yang cukup luas, sehingga akan mempermudah dalam sistem pencatatan dan pelaporannya (Hari, 2012).

\section{METODOLOGI PENELITIAN Pengumpulan Data}

Data yang dikumpulkan yaitu data sekunder yang diperoleh dalam bentuk yang sudah jadi dan dikumpulkan oleh pihak RSUD DR Moewardi. Data-data tersebut diperoleh dari bagian sub gudang obat Instalasi Farmasi RSUD DR Moewardi. Data sekunder yang dikumpulkan berupa :

1. Data Obat gawat darurat

2. Data Status Persediaan Obat gawat darurat

3. Data Nilai Pemakaian Obat gawat darurat

4. Data Kebutuhan Aktual Obat gawat darurat

\section{Pengolahan Data}

Pada tahap ini, data-data yang telah diperoleh pada tahap pengumpulan data, kemudian dilakukan pengolahan terhadap data-data tersebut. Langkah-langkah penelitian bisa dilihat pada Gambar 1. 


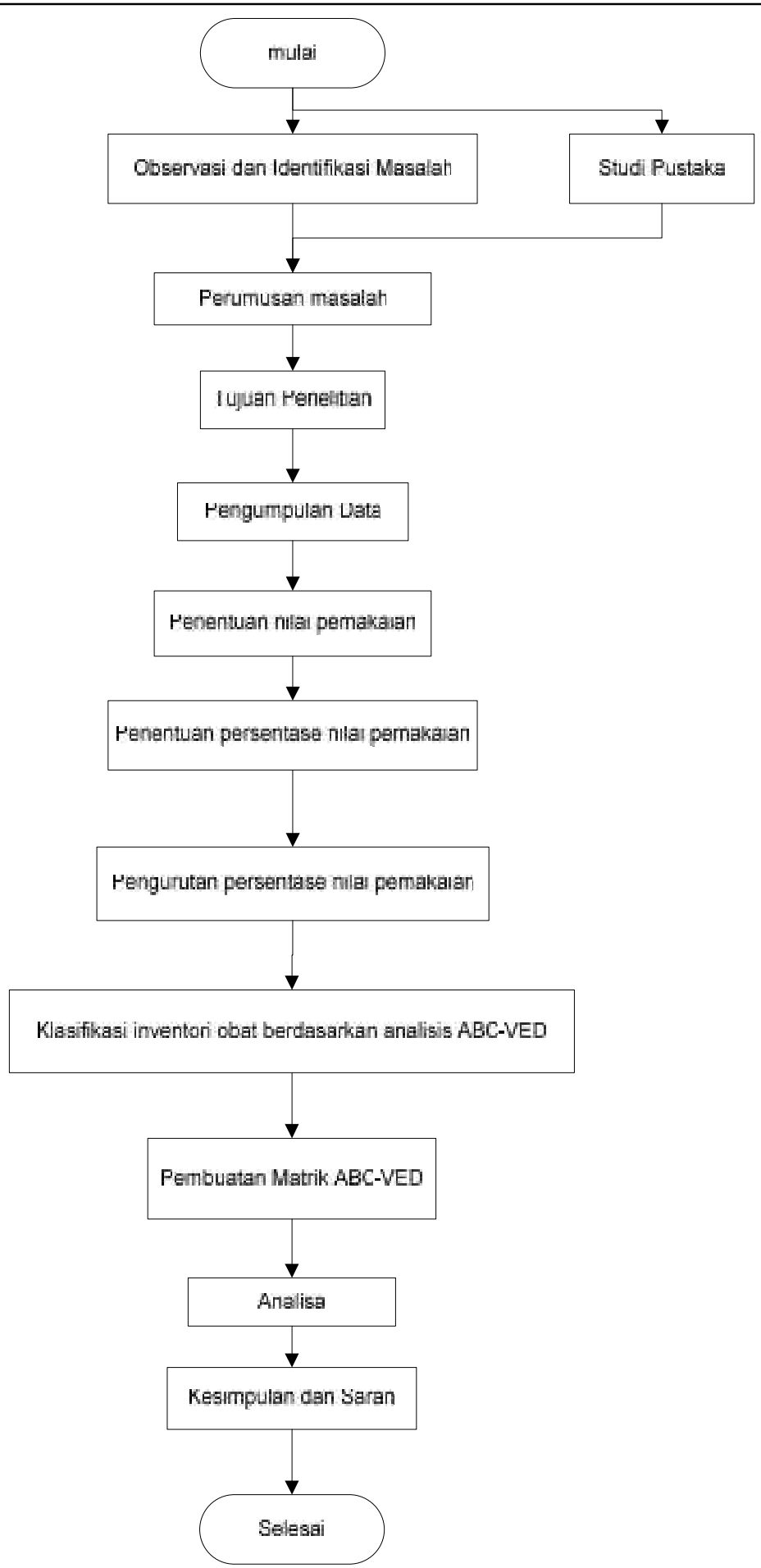

Gambar 1. Metodologi Penelitian

\section{Klasifikasi Obat Gawat Darurat menggunakan Analisis $A B C$ dan Analisis VED.}

Klasifikasi obat gawat darurat menggunakan analisis $A B C$ bertujuan untuk mengklasifikasikan obat dalam susunan menurun berdasarkan nilai investasi yang terpakai (nilai pemakaian obat) per satuan waktu. Hasil dari klasifikasi ini adalah kategori obat yang berupa obat kategori $A$, $B$, dan $C$. Obat kategori A menggambarkan investasi yang lebih besar dalam inventori, maka perlu lebih berhati-hati dalam membuat keputusan tentang kuantitas pemesanan dan waktu pemesanan terhadap obat kategori $\mathrm{A}$ dibandingkan terhadap obat kelas $B$ dan $C$. 
Langkah-langkah yang dilakukan

dalam analisis $\mathrm{ABC}$ adalah sebagai berikut :

1. Penentuan nilai pemakaian dari setiap obat gawat darurat.

Nilai pemakaian obat ke- g diperoleh dari jumlah pemakaian obat ke- $g$ dikali harga obat ke- $\mathrm{g}$

$b_{g}=R_{g} \times C_{g}$

Keterangan :

bg : Nilai pemakaian obat ke- $g$ (Rupiah)

$\mathrm{Rg}$ : Jumlah kebutuhan obat ke- $\mathrm{g}$ (Unit)

$\mathrm{Cg}$ : Harga obat ke-g (Rupiah)

2. Penentuan persentase nilai pemakaian dari setiap obat gawat darurat.

Total nilai pemakaian obat diperoleh dari penjumlahan nilai pemakaian obat ke- $g$ sampai obat ke- $\mathrm{h}$.

$B=\sum_{g=1}^{h} b_{g}$

Persentase nilai pemakaian diperoleh dari nilai pemakaian obat ke-g dibagi total nilai pemakaian dikali $100 \%$.

$B_{g}=\frac{b_{g}}{B} \times 100 \%$

Keterangan :

bg : Nilai pemakaian obat ke- $g$ (Rupiah)

B : Total nilai pemakaian obat (Rupiah)

$\mathrm{Bg}$ : Persentase nilai pemakaian obat $(\%)$

3. Mendaftar obat dalam rank persentase nilai pemakaian dengan urutan menurun dari terbesar sampai terkecil.

4. Mengklasifikasikan inventori obat ke dalam kategori A, B, C dan V, E, D berdasarkan analisis ABC dan VED.

Menurut Herjanto (1999), kriteria masingmasing kelas adalah :

a. Obat yang mengkonsumsi $70 \%$ total nilai pemakaian obat dimasukkan dalam Grup A.

b. Obat yang mengkonsumsi $20 \%$ total nilai pemakaian obat dimasukkan dalam Grup B.

c. Obat yang mengkonsumsi $10 \%$ total nilai pemakaian obat dimasukkan dalam Grup C.

Klasifikasi obat gawat darurat menggunakan analisis VED bertujuan untuk mengklasifikasikan obat berdasarkan kekritisan waktu pemberian obat kepada pasien. Obat kategori Vital adalah obat yang sangat dibutuhkan pasien dengan segera untuk menyelamatkan hidup, obat kategori mutlak tersedia sepanjang waktu dalam persediaan ruangan. Kekosongan obat jenis ini akan berakibat fatal dan tidak dapat ditoleransi. Obat kategori Essential adalah obat yang dibutuhkan oleh pasien, kekritisan waktu pemberian obat lebih rendah daripada kategori vital, masih ada toleransi kekosongan selama tidak lebih dari 24 jam. Obat kategori Desirable adalah obat yang dibutuhkan oleh pasien, kekritisan waktu pemberian obat paling rendah daripada Vital dan Essential. Obat ini biasanya dalam sediaan oral untuk penanganan pasien lebih lanjut, masih ada toleransi kekosongan selama tidak lebih dari 48 jam. Status obat kategori Vital, Essential, Desirable berdasarkan data dari RSUD Dr Moewardi Surakarta.

5. Membuat Matrik ABC - VED.

Membuat matrik berdasarkan hasil analisis $A B C$ dan VED, berdasarkan matrik tersebut obat dibedakan dalam dua prioritas. Prioritas I merupakan obat yang membutuhkan prioritas manajemen yang lebih besar dalam pengendaliannya yaitu kelompok $\mathrm{AV}, \mathrm{AE}, \mathrm{AD}$, $\mathrm{BV}$, dan $\mathrm{BE}$. Prioritas II merupakan obat yang membutuhkan prioritas manajemen yang lebih rendah dalam pengendalianya yaitu kelompok BD, CV, CE, dan CD (abjad pertama menyatakan analisis $A B C$ dan abjad kedua menyatakan analisis VED).

\section{HASIL DAN PEMBAHASAN \\ Klasifikasi Obat Gawat Darurat menggunakan Analisis ABC dan Analisis VED.}

Klasifikasi obat gawat darurat menggunakan analisis $A B C$ bertujuan untuk mengklasifikasikan obat dalam susunan menurun berdasarkan nilai investasi yang terpakai (nilai pemakaian obat) per satuan waktu. Hasil dari klasifikasi ini adalah kategori obat yang berupa obat kategori $A$, $\mathrm{B}$, dan $\mathrm{C}$. Obat kategori A menggambarkan investasi yang lebih besar dalam inventori, maka perlu lebih berhati-hati dalam membuat keputusan tentang kuantitas pemesanan dan waktu pemesanan terhadap obat kategori A dibandingkan terhadap obat kelas $\mathrm{B}$ dan $\mathrm{C}$.

Langkah-langkah yang dilakukan dalam analisis $A B C$ adalah sebagai berikut : 
1. Penentuan nilai pemakaian dari setiap obat gawat darurat.

Nilai pemakaian obat diperoleh dari jumlah pemakaian obat dikali harga obat. Contoh nilai pemakaian obat item ke- 1 adalah :

$$
\begin{aligned}
b_{1} & =R_{1} \times C_{1} \\
& =170 \times \text { Rp. } 2.310 .000 \\
& =\text { Rp. } 392.700 .000
\end{aligned}
$$

2. Penentuan persentase nilai pemakaian dari setiap obat gawat darurat.

Total nilai pemakaian diperoleh dari penjumlahan nilai pemakaian obat ke-1 sampai obat ke- 144 adalah :

$$
B=\sum_{g=1}^{144} b_{g}
$$$$
B=(392.700 .000,-+287.941 .500,-+
$$

Persentase nilai pemakaian diperoleh dari nilai pemakaian obat dibagi total nilai pemakaian dikali 100\%. Contoh persentase nilai pemakaian obat item ke1 adalah :

$$
B_{1}=\frac{b_{1}}{B} \times 100 \%=\frac{392.700 .000}{4.702 .741 .279} \times 100 \%=8,350
$$

3. Mendaftar obat dalam rank persentase total nilai pemakaian dengan urutan menurun dari terbesar sampai terkecil.

Pada langkah ini persentase total nilai pemakaian diurutkan dari terbesar sampai terkecil. Persentase total nilai pemakaian terbesar adalah Sevorane (Sevoflurane) $250 \mathrm{ml}$ yaitu $8,35045 \%$ dan persentase total nilai pemakaian terkecil adalah Phenobarbital $30 \mathrm{mg}$ tablet yaitu $0,00125 \%$.

4. Mengklasifikasikan inventori obat ke dalam kelas A, B, C dan V, E, D berdasarkan analisis $A B C$ dan VED.

Membuat Matrik ABC - VED.

Membuat matrik berdasarkan hasil analisis ABC dan VED, berdasarkan matrik tersebut obat dibedakan dalam 2

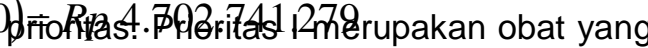
membutuhkan prioritas manajemen yang lebih besar dalam pengendaliannya yaitu kelompok $\mathrm{AV}, \mathrm{AE}, \mathrm{AD}, \mathrm{BV}$, dan $\mathrm{BE}$. Prioritas II merupakan obat yang membutuhkan prioritas manajemen yang lebih rendah dalam pengendalianya yaitu kelompok BD, CV, CE, dan CD (abjad derfama menyatakan analisis $A B C$ dan abjad kedua menyatakan analisis VED). Matrik analisis ABC dan VED terdapat pada Tabel

Tabel 2 Matrik Analisis ABC dan Analisis VED

\begin{tabular}{ccccccc}
\hline Kategori Obat & \multicolumn{2}{c}{ A } & \multicolumn{2}{c}{ B } & \multicolumn{2}{c}{ C } \\
& Persentase & Jmh Obat & Persentase & Jmh Obat & Persentase & Jmh Obat \\
\hline V & $\mathbf{3 6 , 9 2}$ & $\mathbf{1 1}$ & $\mathbf{1 2 , 4 8 2 6}$ & $\mathbf{1 7}$ & 1,58 & 17 \\
E & $\mathbf{2 2 , 6 8}$ & $\mathbf{9}$ & $\mathbf{6 , 2 7 8 9}$ & $\mathbf{9}$ & 4,51 & 41 \\
D & $\mathbf{9 , 7 7}$ & $\mathbf{3}$ & 0,9005 & 1 & 4,88 & 36 \\
\hline
\end{tabular}

Keterangan : Cetak Tebal : Prioritas I, Normal : Prioritas II

Dari Tabel 2 terlihat bahwa obat prioritas I mengkonsumsi $88,13 \%$ dari total nilai pemakaian. Obat jenis ini mempunyai nilai investasi dan pemakaian yang tinggi sehingga obat jenis ini membutuhkan kontrol yang lebih. Misalnya obat kelas A kategori Vital diantaranya Sevorane ( Sevoflurane ) $250 \mathrm{ml}$, Na Phenytoin inj, Halothane $250 \mathrm{ml}$, Ringer Lactat $500 \mathrm{ml}$ inf plastik, OMZ inj 10ml, Plasbumin $25 \% 50$ $\mathrm{ml}$, Fluothane $250 \mathrm{ml}$, Dextrose $5 \% 500 \mathrm{ml}$ inf plastik, Plasbumin $20 \% 50 \mathrm{ml}$, Recofol $20 \mathrm{ml}$ inj. Obat tersebut mempunyai nilai pemakaian yang tinggi dan dari segi kekritisan pemakaian termasuk kategori Vital yang mutlak harus tersedia di sepanjang waktu dalam persediaan ruangan, tidak ada toleransi kekosongan tehadap obat jenis ini sehingga kontrol pengadaaannya harus diperhatikan. Obat jenis ini banyak dibutuhkan di Unit Gawat Darurat dan Instalasi bedah Sentral untuk menangani /memberikan pertolongan pada pasien akut untuk menyelamatkan jiwa dan mencegah kecatatan seumur hidup. Dari Tabel 2 juga terlihat ada obat kelas B kategori Desirable yang mempunyai prosentase nilai pemakaian terkecil, obat ini merupakan obat dalam sediaan oral untuk penyembuhan pasien lebih lanjut. Dari segi pemakaiannnya yang kecil dan dari tingkat kekritisannya yang rendah (ada toleransi kekosongan) maka obat ini tidak membutuhkan perhatian khusus. Tabel 2 juga menunjukkan bahwa ada 17 obat kategori $\mathrm{C}$ yang merupakan obat Vital, obat jenis ini tidak ada toleransi kekosongan sehingga pengawasannya juga harus diperhatikan jangan sampai terjadi kekosongan untuk obat jenis ini. Walaupun jumlah obat kategori C Vital ini jenisnya 
cukup banyak tetapi total nilai pemakaiannya kecil yang berarti tingkat pemakaiannya sedikit.

\section{Kesimpulan}

Dari penelitian pengendalian persediaan obat gawat darurat di Sub
Gudang obat Instalasi Farmasi RSUD Dr Moewardi dapat disimpulkan bahwa dengan menggunakan klasifikasi ABC dan VED, terdapat 49 jenis obat gawat darurat prioritas I dan 95 jenis obat gawat darurat prioritas II, untuk mempermudah pengendalian obat gawat darurat.

\section{DAFTAR PUSTAKA}

Fogarty, D.W. et al. (1991). Production \& Inventory Mangement. South Western Publishing Co.

Hari, Lukito (2012). Thesis. Analisis Perencanaan Obat Berdasarkan Klasifikasi ABC dan Epidemiologi Klinik di Instalasi Farmasi Rumah Sakit Islam PKI Muhammadiyah Kabupaten Tegal. Magister Manajemen, Universitas Soedirman, Purwokerto.

Herjanto, Eddy. (1999). Manajemen Produksi dan Operasi. PT Gramedia Widiasarana Indonesia, Jakarta.

Suciati, Susi dan Adisasmito, Wiku. (2006). "Analisis Perencanaan Obat Berdasarkan ABC Indeks Kritis di Instalasi Farmasi". Jurnal Manajemen Pelayanan Kesehatan No. 01 Maret (2006). Volume 09. Halaman 19-26.

Thawani VR et al. (2004) "Economic analysis of drug expenditure in Government Medical College hospital, Nagpur." The Indian Journal of Pharmacology 36 (2004). Page 15-19.

Yuliastuti, Beti. (2006). Skripsi. Pengendalian Persediaan Obat Gawat Darurat di Sub Gudang Obat Instalasi Farmasi RSUD Dr. Moewardi Surakarta. Jurusan Teknik Industri Fakultas Teknik, Universitas Sebelas Maret, Surakarta. 